\title{
Penentuan Tata Letak Gudang Sparepart Non Genuine Pada Bengkel Mobil di Surabaya dengan Metode Dedicated Storage
}

\author{
Kelvin, Departemen Teknik Industri, Institut Sains dan Teknologi Terpadu Surabaya, Pram Eliyah \\ Yuliana, Departemen Teknik Industri, Institut Sains dan Teknologi Terpadu Surabaya, dan Sri \\ Rahayu, Departemen Teknik Industri, Institut Sains dan Teknologi Terpadu Surabaya
}

\begin{abstract}
Abstrak-Gudang merupakan tempat kegiatan yang berhubungan dengan penyimpanan barang. Manajemen gudang yang baik tentunya akan membantu mempercepat proses keluar dan masuk barang. Permasalahan yang dihadapi sebuah bengkel mobil resmi yang berada di Surabaya adalah tidak adanya manajemen penataan gudang yang baik, khususnya pada gudang sparepart non genuine. Sparepart dengan jumlah lebih dari 90 jenis part tidak tertata dengan baik, sehingga mengakibatkan pencarian sparepart yang dibutuhkan menjadi sulit karena lokasi barang yang tidak terdeteksi. Untuk mengatasi permasalahan tersebut, perlu dilakukan perbaikan tata letak gudang dengan menggunakan metode yang sesuai. Salah satu metode yang dapat diterapkan adalah metode Dedicated storage. Metode ini menentukan lokasi yang tetap untuk setiap jenis barang berdasarkan jumlah dan jarak perpindahannya. Sehingga setiap barang nantinya akan memiliki lokasi yang pasti dan jarak ditempuh setiap barang akan menjadi lebih pendek. Data yang diperlukan dalam analisis ini adalah data jenis barang, volume barang, jumlah keluar dan masuk barang, jarak perpindahan barang. Dari hasil analisis pada gudang sparepart non genuine didapatkan 2 kelompok jenis barang yang ditata, yaitu jenis sparepart berupa cairan / basah, dan jenis sparepart kering. Dari 2 kelompok jenis sparepart tersebut dibagi ke dalam 6 (enam) lokasi penyimpanan yang baru dengan 5 (lima) rak memuat barang bersifat basah dan 1 (satu) rak etalase memuat barang bersifat kering. Hasil perhitungan jarak perpindahan sparepart dengan penataan lokasi yang baru didapatkan sebesar 12.942,2 meter perbulan, dimana angka ini berkurang sebanyak $24 \%$ dari $17.047,6$ meter perbulan sebelum dilakukan perbaikan.
\end{abstract}

Kata Kunci-Dedicated Storage, Gudang, Tata Letak.

\section{PENDAhuluan}

$\mathrm{G}$ udang merupakan salah satu fasilitas yang dimiliki setiap perusahaan dengan fungsi sebagai tempat penyimpanan logistik, bahan baku, hingga produk jadi[1].

Oktober 2020

Kelvin, Departemen Teknik Industri, Institut Sains dan Teknologi Terpadu Surabaya, Surabaya, Jawa Timur, Indonesia (e-mail: kelvin@stts.edu)

Pram Eliyah Yuliana, Departemen Teknik Industri, Institut Sains dan Teknologi Terpadu Surabaya, Surabaya, Jawa Timur, Indonesia (e-mail: pram@stts.edu)

Sri Rahayu, Departemen Teknik Industri, Institut Sains dan Teknologi Terpadu Surabaya, Surabaya, Jawa Timur, Indonesia (e-mail: rahayu@stts.edu)
Untuk dapat mendukung berjalannya proses poduksi yang efisien, maka diperlukan manajemen gudang yang baik. Halhal yang menjadi fokus dalam pengelolaan manajemen gudang adalah barang dapat didistribusikan dengan keadaan yang baik, dalam jumlah yang sesuai dan waktu yang tepat. Hal ini pula yang diharapkan dapat dijalankan pada gudang di salah satu bengkel mobil resmi di Surabaya.

Pada bengkel ini terdapat dua gudang yang dibedakan berdasarkan kebutuhannya. Gudang pertama adalah gudang sparepart, dimana ini digunakan untuk menyediakan barang-barang yang bersifat genuine atau sparepart resmi yang diproduksi oleh perusahaan pemegang merk. sedangkan yang kedua adalah gudang non-genuine, dimana gudang ini memiliki peran untuk menyimpan barang-barang selain sparepart resmi yang diproduksi perusahaan dan bersifat pendukung seperti oli, aki, gasket, penetrant, dan sebagainya. Pada gudang non genuine jumlah barang yang tersimpan lebih dari 100 jenis produk dengan luas gudang sebesar $25 \mathrm{~m} 2$ dan juga tenaga kerja yang bertanggungjawab pada gudang ini hanya 1 orang. Dengan aliran keluar masuk barang yang cukup tinggi, maka permasalahan yang dirasakan adalah produk tidak tertata secara tepat dalam gudang ini. Produk tidak memiliki lokasi yang pasti, sehingga dalam proses pencarian barang akan membutuhkan waktu yang lama, terutama jika tenaga kerja yang bertanggung jawab terhadap gudang tidak dapat masuk kerja, maka karyawan lain yang menggantikan akan mengalami kesulitan dalam mencari produk dalam gudang. Akibatnya adalah waktu angkut menjadi lebih lama (ada proses mencari karena letak barang yang tidak beraturan) dan terjadi penumpukan produk yang berlebihan karena permasalahan dalam menentukan jumlah stok. Dari permasalahan tersebut, maka diperlukan penataan gudang yang lebih baik dengan menggunakan metode dedicated storage agar proses yang terjadi di gudang lebih efisien.

\section{RUMUSAN MASALAH}

Rumusan masalah dari permasalahan yang ada adalah bagaimana tata letak gudang non genuine yang baik agar proses yang berjalan lebih efisien. Berdasarkan rumusan masalah ini, maka ditetapkan tujuan penelitian adalah:

1) Merancang tata letak gudang non genuine yang lebih baik. 


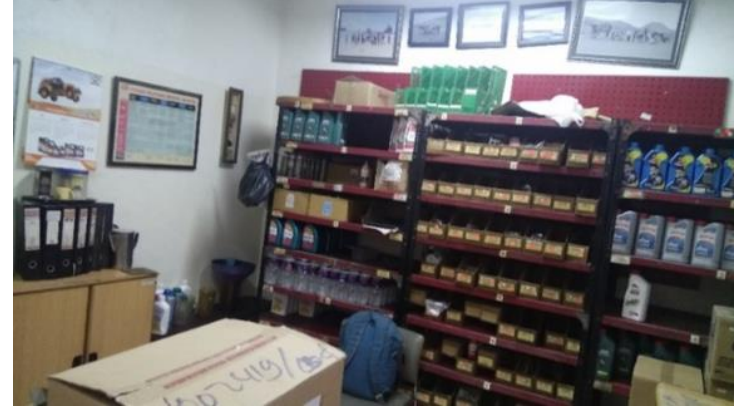

Gambar. 1. Kondisi Gudang

2) Menentukan efisiensi proses dari rancangan tata letak gudang non genuine yang baru.

\section{LANDASAN TEORI}

\section{A. Perancangan Gudang}

Gudang merupakan suatu fasilitas yang berhubungan dengan penyimpanan barang. Barang yang disimpan di gudang antara lain bahan baku, barang perlengkapan, barang setengah jadi, maupun barang jadi. Fungsi utama dari aktivitas gudang adalah memelihara dan melindungi barang sampai barang itu digunakan atau dikirim ke tempat lain. Perancangan gudang sangat dipengaruhi oleh berbagai macam hal yang berhubungan dengan penanganan material (material handling). Prinsip-prinsip dalam perancangan fasilitas gudang perlu menyesuaikan dengan kebutuhan penanganan material yang terjadi di dalam sistem pergudangan. Prinsip-prinsip tersebut adalah sebagai berikut[2]:

1) Penyediaan lorong (aisle) dan lebar lorong yang memadai pada area yang penting.

2) Mempertimbangkan aliran barang dan volume barang untuk diletakkan pada area penyimpanan.

3) Mempertimbangkan akumulasi stock-keeping unit (SKU) yang memadai terlebih dahulu untuk setiap stasiun kerja.

4) Mempertimbangkan tinggi langit-langit yang memadai, sesuai dengan peralatan warehouse.

5) Mempertimbangkan kebutuhan ruang untuk keamanan dan perlindungan terhadap kebakaran.

6) Penempatan aktivitas administrasi atau aktivitas lain yang mendukung.

7) Penempatan fasilitas bangunan pada lokasi yang tepat untuk mendukung ekspansi di masa depan.

8) Penempatan fungsi utama warehouse untuk mendukung ekspansi di masa depan.

9) Merancang lajur dan ukuran ruang bangunan yang memudahkan aliran barang dan aktivitas tenaga kerja.

10) Mempertimbangkan penggunaan gravity-propelled transportation yang dikombinasikan dengan perlengkapan mekanik dan otomatis.

\section{B. Metode Penyimpanan dalam Gudang}

Menurut Francis ada empat metode yang dapat digunakan untuk mengatur lokasi penyimpanan suatu barang[3], yaitu:

1) Metode dedicated storage

Metode ini sering disebut sebagai penyimpanan yang sudah tertentu dan tetap karena lokasi untuk tiap barang sudah ditentukan tempatnya. Jumlah lokasi penyimpanan untuk suatu produk harus dapat mencukupi kebutuhan ruang penyimpanan yang paling maksimal dari produk tersebut. Ruang penyimpanan yang diperlukan adalah kumulatif dari kebutuhan penyimpanan maksimal dari tiap jenis produknya jika produk yang akan disimpan lebih dari satu jenis.

2) Metode randomized storage

Metode ini sering disebut dengan floating lot storage, yaitu penyimpanan yang memungkinkan produk yang disimpan berpindah lokasi penyimpanannya setiap waktu. Penempatan barang hanya memperhatikan jarak terdekat menuju suatu tempat penyimpanan dengan perputaran penyimpanannya menggunakan sistem FIFO (First In First Out). Faktor-faktor lain seperti jenis barang yang disimpan, dimensi, dan jaminan keamanan barang kurang diperhatikan. Hal ini membuat penyimpanan barang menjadi kurang teratur.

3) Metode class-based dedicated storage

Metode ini adalah kompromi dari metode randomized storage dan dedicated storage. Metode ini menjadikan produk-produk yang ada dibagi ke dalam tiga, empat, atau lima kelas didasarkan pada perbandingan throughput (T) dan ratio storage $(\mathrm{S})$. Metode ini membuat pengaturan tempat dirancang lebih fleksibel yaitu dengan cara membagi tempat penyimpanan menjadi beberapa bagian. Tiap tempat tersebut dapat diisi secara acak oleh beberapa jenis barang yang telah diklasifikasikan berdasarkan jenis maupun ukuran dari barang tersebut.

4) Metode shared storage

Para manajer gudang menggunakan variasi dari metode dedicated storage sebagai jalan keluar untuk mengurangi kebutuhan ruang penyimpanan dengan penentuan produk secara lebih hati-hati terhadap ruang yang dipakai. Produkproduk yang berbeda menggunakan slot penyimpanan yang sama, walaupun hanya satu produk menempati satu slot ketika slot tersebut terisi. Model penyimpanan seperti ini yang dinamakan shared storage. Kebutuhan ruang yang diperlukan untuk metode shared storage berkisar antara kebutuhan ruang untuk metode randomized storage dan dedicated storage tergantung dari banyaknya informasi yang tersedia mengenai level persediaan selama kurun waktu tertentu. Metode shared storage dan randomized storage memiliki perbedaan. Metode randomized storage berkenaan dengan spesifikasi total lokasi penyimpanan dari produk. Metode shared storage berkenaan dengan lokasi yang bergantung pada munculnya tempat kosong dalam gudang. Metode shared storage lebih cocok digunakan jika produk yang disimpan bermacam-macam jenisnya dengan permintaan yang relatif konstan.

\section{Dedicated Storage}

Terdapat tiga langkah yang harus dilakukan untuk dapat melaksanakan dedicated storage policy, yaitu:

\section{1) Space Requirement}

Space requirement merupakan perhitungan untuk menentukan lokasi penyimpanan produk tertentu. Formula (1) bertujuan untuk memastikan bahwa hanya terdapat satu produk yang ditempatkan pada lokasi penyimpanan rak 
gudang Berikut ini merupakan formulasi yang digunakan untuk menghitung space requirement.

$$
\text { kebutuhan ruang }=\frac{(\text { Luas tiap produk }) \times \text { penyimpanan maksimum } \text { produk }}{\text { kapasitas penyimpanan produk } \text { per slot }}
$$

\section{2) Perhitungan Throughput}

Perhitungan throughput bertujuan untuk mengetahui nilai aktivitas penerimaan/pengambilan produk rata-rata per bulan. Berikut ini merupakan formulasi yang digunanakan untuk menghitung throughput:

$T=\frac{\text { aktivitas penerimaan rata2 } \text { per hari }}{\text { jumlah pemindahan sekali angkut }}+\frac{\text { aktivitas pengiriman rata2 } \text { per hari }}{\text { jumlah pemindahan sekali angkut }}$

\section{3) Penempatan Produk (Assignment)}

Perankingan produk berdasarkan perbandingan throughput $(\mathrm{Tj})$ dengan storage $(\mathrm{Sj})$. Perankingan produk bertujuan untuk mengetahui produk yang memiliki tingkat kepentingan yang tinggi dari antara produk-produk yang ada. Produk dengan tingkat kepentingan tinggi dapat diketahui dari nilai perbandingan T/S yang tinggi. Formulasi yang digunakan untuk menghitung ranking tersebut adalah:

$$
T / S=\frac{\text { Troughput }}{\text { Kebutuhan ruang }}
$$

\section{FIFO (First In First Out)}

Menurut Tompkins dan Smith[4], Metode FIFO (first in first out) menganggap bahwa harga pokok dari barangbarang yang pertama kali dibeli akan merupakan barang yang dijual pertama kali. Dalam metode ini persediaan akhir dinilai dengan harga pokok pembelian yang paling akhir. Metode ini juga mengasumsikan bahwa barang yang terjual karena pesanan adalah barang yang mereka beli. Oleh karenanya, barang-barang yang dibeli pertama kali adalah barang-barang pertama yang dijual dan barang-barang sisa di tangan (persediaan akhir) diasumsikan untuk biaya akhir. Karenanya, untuk penentuan pendapatan, biaya-biaya sebelumnya dicocokkan dengan pendapatan dan biaya-biaya yang baru digunakan untuk penilaian laporan neraca. Metode ini konsisten dengan arus biaya aktual, sejak pemilik barang dagang mencoba untuk menjual persediaan lama pertama kali. FIFO merupakan yang paling luas digunakan dalam penilaian persediaan.

Metode FIFO seringkali tidak nampak secara langsung pada aliran fisik dari barang tersebut karena pengambilan barang dari gudang lebih didasarkan pada pengaturan barangnya. Dengan demikian metode FIFO lebih nampak pada perhitungan harga pokok barang. Dalam metode FIFO, biaya yang digunakan untuk membeli barang pertama kali akan dikenali sebagai Cost of Goods Sold (COGS). Pada metode FIFO, persediaan barang yang dikeluarkan untuk produksi atau dijual, nilainya didasarkan pada harga menurut urutan yang pertama masuk. Jadi, untuk penilaian pada persediaan barang yang tersisa, berarti harganya didasarkan pada harga baru atau harga urutan yang terakhir.

\section{METODE PENELITIAN}

Langkah-langkah yang dilakukan dalam melakukan penelitian ini antara lain identifikasi masalah, perumusan masalah, studi pustaka, pengumpulan data, pengolahan dan analisis data, dan penarikan kesimpulan. Berikut adalah detail dari langkah-langkah yang dilakukan untuk melaksanakan penelitian ini.

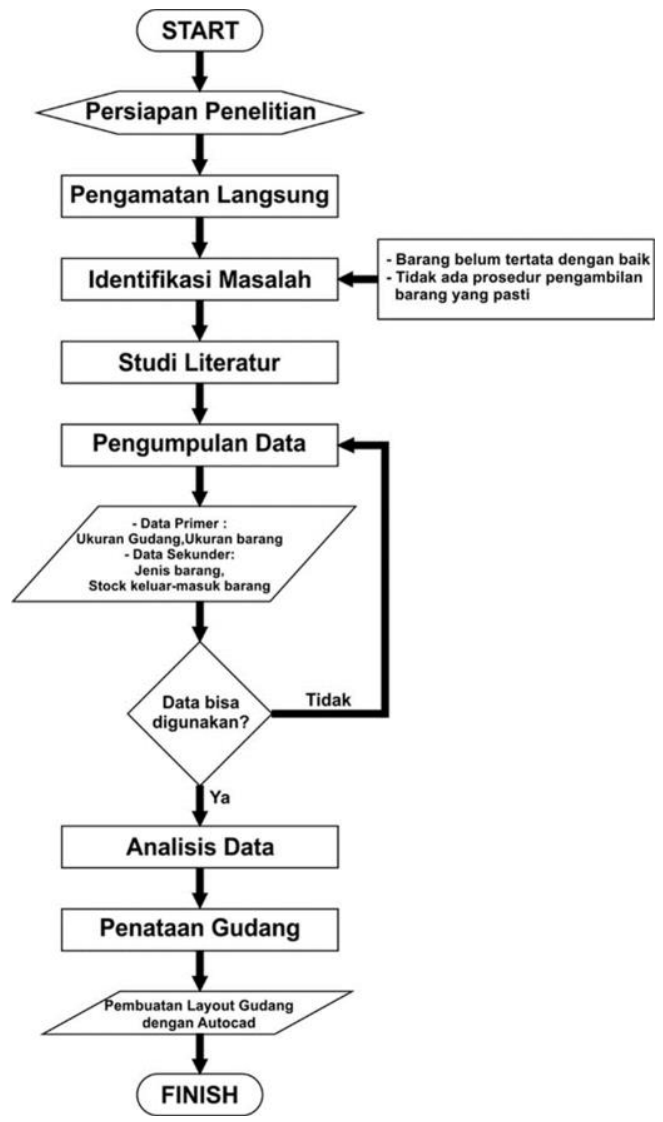

Gambar. 2. Flowchart Metodologi Penelitian

\section{Pengumpulan Data}

\section{A. Layout Gudang Non-genuine}

Pada bengkel mobil ini memiliki luas gudang non genuine memiliki luas area sebesar $25 \mathrm{~m}^{2}$. Gudang ini berfungsi sebagai gudang utama penyedia bahan pendukung untuk melakukan servis kendaraan. Berikut adalah layout dari Gudang non-genuine sebelum dilakukan perbaikan.

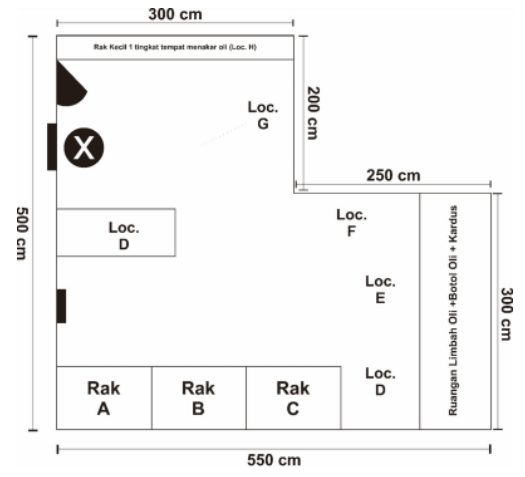

Gambar. 3. Layout Gudang Non genuine 


\section{B. Data Produk di Gudang Non-Genuine}

Produk yang disimpan dalam gudang non-genuine memiliki total 97 jenis produk. Berikut adalah beberapa data jenis produk yang disimpan di dalam gudang tersebut:

TABEL I

TABEL JENIS BARANG PADA GUDANG NON-GENUINE

\begin{tabular}{ccl}
\multicolumn{3}{c}{ TABEL JENIS BARANG PADA GUDANG NON-GENUINE } \\
\hline \hline No & Kode Barang & \multicolumn{1}{c}{ Nama Barang } \\
\hline 1 & DVG66670541 & "GASKET PLUG T/M,DIFF" \\
2 & DVG92F90557 & AC ELEVAPORATOR C.R 250 ML \\
3 & DVG51300541 & ACCU GS NS 40 HYB 12v 32Ah \\
4 & DVG51300541 & ACCU GSNS 40 12V 32 Ah.HYBRID \\
5 & DVG62310541 & ACTUATOR CENTRAL LOCK \\
6 & DVG51B70541 & AIR ACCU AA \\
7 & DVG42420548 & ASTRA SHELL HELIX 10W30 SM \\
8 & DVG42420546 & ASTRA SHELL HELIX 10W40 SL \\
9 & DVG42420550 & ASTRA SHELL HELIX 5W30 SN \\
10 & DVG24681313 & ATF CASTROL DEXTRON III \\
$\cdot$ & & \\
. & & \\
97 & DVG61070548 & WIPER FLUID SAFECLEAN 100ML \\
\hline \hline
\end{tabular}

\section{Data Ukuran Tiap Jenis Produk}

Dari dari jenis produk yang terdata dilakukan pengelompokan menjadi dua tipe yaitu barang yang bersifat basah (liquid) dan barang yang bersifat kering (solid). Hal ini diperlukan karena kedua jenis produk ini perlu mendapatkan lokasi penyimpanan yang terpisah. Dari 97 jenis produk yang sudah dikelompokan selanjutnya dihitung ukuran dimensi tiap barang. Hal ini digunakan untuk menentukan luasan wilayah yang dibutuhkan dalam proses penyimpanan pada gudang dan juga jumlah kapasitas maksimum penyimpanan dalam gudang. Untuk produk yang bersifat basah terdapat 33 jenis, berikut adalah daftar produk yang berjenis basah.

TABEL II

TABEL PRODUK BERSIFAT BASAH (LIQUID)

\begin{tabular}{|c|c|c|c|c|c|c|c|}
\hline \multirow{2}{*}{ No } & \multirow{2}{*}{$\begin{array}{c}\text { Kode } \\
\text { Barang }\end{array}$} & \multirow{2}{*}{ Nama Barang } & \multirow{2}{*}{$\begin{array}{l}\text { Kuant } \\
\text { Satuan }\end{array}$} & \multicolumn{3}{|c|}{ Ukuran CM } & \multirow{2}{*}{$\begin{array}{l}\text { Kaps } \\
\text { maks }\end{array}$} \\
\hline & & & & $\mathrm{P}$ & $\mathrm{L}$ & $\mathrm{T}$ & \\
\hline \multirow[t]{3}{*}{1} & DVG92 & AC EVAPOR & $1 \mathrm{Klg}$ & 6 & 6 & 18 & 120 \\
\hline & F90557 & ATOR CLEA & & & & & $\mathrm{Klg}$ \\
\hline & & $\begin{array}{l}\text { NER ROCK } \\
250 \mathrm{ML}\end{array}$ & & & & & \\
\hline \multirow[t]{2}{*}{2} & DVG513 & ACCU GS NS & $1 \mathrm{Pcs}$ & 30 & 20 & 25 & $6 \mathrm{Pcs}$ \\
\hline & 00541 & $\begin{array}{c}40 \text { HYB } 12 \mathrm{v} \\
32 \mathrm{Ah}\end{array}$ & & & & & \\
\hline \multirow[t]{2}{*}{3} & DVG51 & AIR ACCU AA & $1 \mathrm{Btl}$ & 6 & 6 & 27 & 480 \\
\hline & B70541 & & & & & & Btl \\
\hline \multirow[t]{2}{*}{4} & DVG424 & ASTRA & $1 \mathrm{Btl}$ & 15 & 6 & 23 & 120 \\
\hline & 20548 & $\begin{array}{c}\text { SHELL HELIX } \\
\text { 10W30 SM } \\
\text { (BTL) }\end{array}$ & & & & & Btl \\
\hline \multirow[t]{3}{*}{5} & DVG424 & ASTRA & $1 \mathrm{Btl}$ & 15 & 6 & 23 & 120 \\
\hline & 20546 & SHELL HELIX & & & & & Btl \\
\hline & & $\begin{array}{c}\text { 10W40 SL } \\
\text { (BTL) }\end{array}$ & & & & & \\
\hline \multicolumn{8}{|l|}{. } \\
\hline \multirow[t]{3}{*}{33} & DVG61 & WIPER FLUID & $1 \mathrm{Btl}$ & 7 & 3 & 10 & 120 \\
\hline & O70548 & SAFECLEAN & & & & & Btl \\
\hline & & $100 \mathrm{ML}$ & & & & & \\
\hline
\end{tabular}

Sedangkan untuk produk yang bersifat kering sebanyak 64 jenis. Berikut adalah daftar untuk produk yang bersifat kering.
TABEL III

TABEL PRODUK BERSIFAT KERING (SOLID)

\begin{tabular}{|c|c|c|c|c|c|c|c|}
\hline \multirow{2}{*}{ No } & \multirow{2}{*}{$\begin{array}{c}\text { Kode } \\
\text { Barang }\end{array}$} & \multirow{2}{*}{ Nama Barang } & \multirow{2}{*}{$\begin{array}{l}\text { Kuant } \\
\text { Satuan }\end{array}$} & \multicolumn{3}{|c|}{ Ukuran CM } & \multirow{2}{*}{$\begin{array}{l}\text { Kaps } \\
\text { maks }\end{array}$} \\
\hline & & & & $\mathrm{P}$ & $\mathrm{L}$ & $\mathrm{T}$ & \\
\hline \multirow[t]{2}{*}{1} & DVG666 & "GASKET & 100 & 10 & 5 & 7 & 500 \\
\hline & 70541 & $\begin{array}{c}\text { PLUG } \\
\text { T/M,DIFF." }\end{array}$ & Pcs/pak & & & & Pcs \\
\hline \multirow[t]{2}{*}{2} & DVG623 & ACTUATOR & $1 \mathrm{Pcs}$ & 15 & 4 & 5 & $2 \mathrm{Pcs}$ \\
\hline & 10541 & $\begin{array}{l}\text { CENTRAL } \\
\text { LOCK. }\end{array}$ & & & & & \\
\hline \multirow[t]{2}{*}{3} & DVG40 & BAHAN & $1 \mathrm{Lbr}$ & 40 & 30 & 0 , & 100 \\
\hline & Q90541 & $\begin{array}{c}\text { PEMBERSIH } \\
\text { BR } 3\end{array}$ & & & & 1 & Pcs \\
\hline 4 & $\begin{array}{c}\text { DVG515 } \\
40541\end{array}$ & $\begin{array}{c}\text { BATERAI GP } \\
27 \mathrm{~A}\end{array}$ & $1 \mathrm{Pcs}$ & 5 & 3 & 1 & $\begin{array}{l}25 \\
\text { Pcs }\end{array}$ \\
\hline 5 & $\begin{array}{c}\text { DVG318 } \\
50541\end{array}$ & BAUT MUR 10 & $\begin{array}{c}20 \text { Pcs } \\
/ \text { box }\end{array}$ & 8 & 5 & 5 & $\begin{array}{l}100 \\
\text { Pcs }\end{array}$ \\
\hline - & - & - & - & - & $\cdot$ & - & - \\
\hline . & . & . & . & 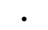 & . & . & ․ \\
\hline 64 & $\begin{array}{c}\text { DVG546 } \\
70541\end{array}$ & TERMINAL 12 & 20 Pcs & 8 & 5 & 5 & $\begin{array}{l}40 \\
\text { Pcs }\end{array}$ \\
\hline
\end{tabular}

\section{Data Mutasi Produk}

Data mutasi produk didapatkan dengan melihat jumlah rata-rata produk yang masuk dan keluar per bulan berdasarkan data mutasi produk selama 3 bulan. Berikut adalah data mutasi produk untuk produk berjenis basah dan produk berjenis kering.

TABEL IV

TABEl RATA - RATA MUtAsi PRODUK BASAH

\begin{tabular}{|c|c|c|c|c|}
\hline No & $\begin{array}{l}\text { Kode } \\
\text { Barang }\end{array}$ & Nama Barang & $\begin{array}{c}\text { Mutasi } \\
\text { Masuk } \\
\text { (Pcs/Dus) }\end{array}$ & $\begin{array}{c}\text { Mutasi } \\
\text { Keluar } \\
\text { (Pcs) }\end{array}$ \\
\hline \multirow[t]{2}{*}{1} & DVG92 & AC EVAPORATOR & 72 Pcs / & 48 Pcs \\
\hline & F90557 & CLEANER ROCK $250 \mathrm{ML}$ & 6 Dus & \\
\hline 2 & $\begin{array}{c}\text { DVG513 } \\
00541\end{array}$ & $\begin{array}{c}\text { ACCU GS NS } 40 \mathrm{HYB} 12 \mathrm{v} \\
32 \mathrm{Ah}\end{array}$ & $4 \mathrm{Pcs}$ & $2 \mathrm{Pcs}$ \\
\hline 3 & $\begin{array}{l}\text { DVG51 } \\
\text { B70541 }\end{array}$ & AIR ACCU AA & $\begin{array}{l}480 \text { Pcs / } \\
20 \text { Dus }\end{array}$ & 456 Pcs \\
\hline 4 & $\begin{array}{l}\text { DVG424 } \\
20548\end{array}$ & $\begin{array}{c}\text { ASTRA SHELL HELIX } \\
\text { 10W30 SM (BTL) }\end{array}$ & $\begin{array}{l}72 \text { Pcs / } \\
6 \text { Dus }\end{array}$ & 63 Pcs \\
\hline 5 & $\begin{array}{l}\text { DVG424 } \\
20546\end{array}$ & $\begin{array}{l}\text { ASTRA SHELL HELIX } \\
\text { 10W40 SL (BTL) }\end{array}$ & $\begin{array}{l}96 \text { Pcs / } \\
8 \text { Dus }\end{array}$ & 87 Pcs \\
\hline - & - & - & - & - \\
\hline . & . & . & . & . \\
\hline \multirow[t]{2}{*}{33} & DVG61 & WIPER FLUID & $120 \mathrm{Pcs} /$ & 100 Pcs \\
\hline & O70548 & SAFECLEAN 100ML & 10 Dus & \\
\hline
\end{tabular}

TABEL V

TABel Rata - RAta Mutasi Produk KeRING

\begin{tabular}{|c|c|c|c|c|}
\hline No & $\begin{array}{c}\text { Kode } \\
\text { Barang }\end{array}$ & Nama Barang & $\begin{array}{c}\text { Mutasi } \\
\text { Masuk } \\
\text { (Pcs/Dus) }\end{array}$ & $\begin{array}{c}\text { Mutasi } \\
\text { Keluar } \\
(\text { Pcs })\end{array}$ \\
\hline 1 & $\begin{array}{c}\text { DVG666 } \\
70541\end{array}$ & $\begin{array}{l}\text { "GASKET PLUG } \\
\text { T/M,DIFF." }\end{array}$ & $\begin{array}{l}300 \text { Pcs } \\
\text { / } 3 \text { Dus }\end{array}$ & $120 \mathrm{Pcs}$ \\
\hline 2 & $\begin{array}{c}\text { DVG623 } \\
10541\end{array}$ & $\begin{array}{l}\text { ACTUATOR CENTRAL } \\
\text { LOCK. }\end{array}$ & $\begin{array}{l}1 \text { Pcs / } \\
1 \text { Dus }\end{array}$ & $1 \mathrm{Pcs}$ \\
\hline 3 & $\begin{array}{l}\text { DVG40 } \\
\text { Q90541 }\end{array}$ & BAHAN PEMBERSIH BR & $\begin{array}{l}80 \text { Pcs / } \\
8 \text { Dus }\end{array}$ & 75 Pcs \\
\hline 4 & $\begin{array}{l}\text { DVG515 } \\
40541\end{array}$ & BATERAI GP 27A & $\begin{array}{l}15 \text { Pcs / } \\
3 \text { Dus }\end{array}$ & $10 \mathrm{Pcs}$ \\
\hline 5 & $\begin{array}{c}\text { DVG318 } \\
50541\end{array}$ & BAUT MUR 10 & $\begin{array}{l}80 \text { Pcs / } \\
4 \text { Dus }\end{array}$ & $20 \mathrm{Pcs}$ \\
\hline$\cdot$ & • & • & • & • \\
\hline$\dot{64}$ & $\begin{array}{c}\dot{ } \\
\text { DVG546 } \\
70541\end{array}$ & TERMINAL 12 & $\begin{array}{l}20 \text { Pcs / } \\
1 \text { Dus }\end{array}$ & $2 \dot{\mathrm{Pcs}}$ \\
\hline
\end{tabular}

\section{E. Data Jarak Perpindahan Produk}

Pada gudang non genuine saat ini terdapat 8 (delapan) lokasi penyimpanan barang. Tiap lokasi selanjutnya dihitung 
jarak perjalanannya menggunakan garis tegak lurus (orthogonal) terhadap titik $\mathrm{x}$ yang dikenal dengan metode rectilinier distance. Salah satu pertimbangan dalam menghitung jarak adalah titik tengah lokasi tersebut dan tidak menghiraukan layer setiap raknya. Berikut adalah layout perpindahan produk pada gudang non genuine.

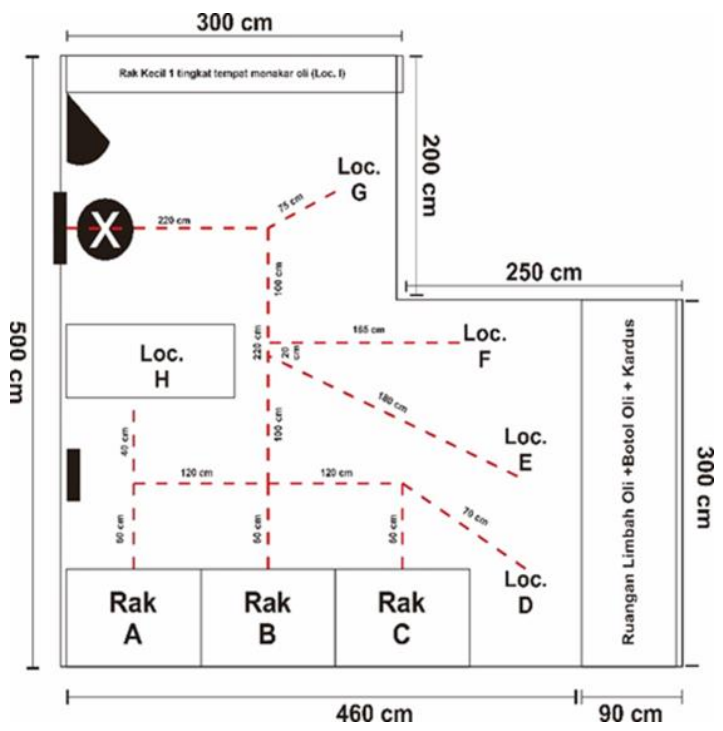

Gambar. 4. Layout Perpindahan Produk pada Gudang Non Genuine

Hasil perhitungan jarak perpindahan untuk masingmasing produk dapat dilihat pada tabel berikut ini.

TABEL VI

TABEL JARAK PERPINDAHAN TIAP PRODUK

\begin{tabular}{|c|c|c|c|c|}
\hline No & $\begin{array}{l}\text { Kode } \\
\text { Barang }\end{array}$ & Nama Barang & Lokasi & Jarak \\
\hline 1 & $\begin{array}{c}\text { DVG666 } \\
70541\end{array}$ & $\begin{array}{l}\text { "GASKET PLUG } \\
\text { T/M,DIFF." }\end{array}$ & Loc. $\mathrm{H}$ & $6 \mathrm{~m}$ \\
\hline 2 & $\begin{array}{l}\text { DVG92 } \\
\text { F90557 }\end{array}$ & $\begin{array}{c}\text { AC EVAPORATOR } \\
\text { CLEANER ROCK } 250 \mathrm{ML}\end{array}$ & Rak A & $6,2 \mathrm{~m}$ \\
\hline 3 & $\begin{array}{c}\text { DVG513 } \\
00541\end{array}$ & $\begin{array}{c}\text { ACCU GS NS } 40 \text { HYB } 12 v \\
\text { 32Ah }\end{array}$ & Loc. D & $6,3 \mathrm{~m}$ \\
\hline 4 & $\begin{array}{c}\text { DVG623 } \\
10541\end{array}$ & $\begin{array}{l}\text { ACTUATOR CENTRAL } \\
\text { LOCK. }\end{array}$ & Rak B & $5 \mathrm{~m}$ \\
\hline 5 & $\begin{array}{l}\text { DVG51 } \\
\text { B70541 }\end{array}$ & AIR ACCU AA & Loc. $\mathrm{G}$ & $2,95 \mathrm{~m}$ \\
\hline . & . & . & . & . \\
\hline 97 & $\begin{array}{l}\text { DVG61 } \\
\text { O70548 }\end{array}$ & $\begin{array}{c}\text { WIPER FLUID } \\
\text { SAFECLEAN 100ML }\end{array}$ & Rak B & $5 \mathrm{~m}$ \\
\hline
\end{tabular}

\section{ANALISIS DATA}

\section{A. Perhitungan Kebutuhan Area Penyimpanan Produk}

Peletakan produk yang disimpan pada gudang akan ditata pada rak-rak yang telah tersedia. Rak yang tersedia memiliki spesifikasi yang berbeda-beda, antara lain Rak A, Rak B, dan Rak C memiliki ukuran panjang $60 \mathrm{~cm}$, lebar $120 \mathrm{~cm}$, dan memiliki 7 layer rak dengan tinggi antar tiap layernya $30 \mathrm{~cm}$. Rak pada loc D memiliki ukuran panjang $60 \mathrm{~cm}$, lebar $200 \mathrm{~cm}$, dan memiliki 6 layer rak dengan tinggi antar tiap layernya $30 \mathrm{~cm}$. Rak pada loc E memiliki ukuran panjang $40 \mathrm{~cm}$, lebar $120 \mathrm{~cm}$, dan hanya memiliki 2 layer dengan tinggi antar layer $30 \mathrm{~cm}$. Kelima rak tersebut digunakan sebagai penyimpanan produk / barang yang bersifat basah / liquid. Dan untuk memudahkan perhitungan blok, setiap blok diasumsikan dengan luasan blok pada tiap layer adalah $20 \mathrm{~cm}$ X $20 \mathrm{~cm}$ dimana tiap blok memiliki luasan $400 \mathrm{~cm} 2$.

Sebagai contoh perhitungan produk / barang pada gudang non-genuine yaitu "AC EVAPORATOR CLEANER ROCK 250 ML" memiliki ukuran dimensi panjang $6 \mathrm{~cm}$, lebar 6 $\mathrm{cm}$, dan tinggi $18 \mathrm{~cm}$. Jumlah penyimpanan maksimum adalah 120 botol. Maka perhitungan dengan menggunakan rumus kebutuhan ruang adalah sebagai berikut:

$$
\text { AC EVAPORATOR CLEANER ROCK } 250 M L=\frac{(6 \times 6) \times 120}{20 \times 20}=10,8
$$

Total luas ruangan yang dibutuhkan adalah $4.320 \mathrm{~cm} 2$ dibagi dengan luas blok $400 \mathrm{~cm} 2$ maka total kebutuhan ruang untuk "AC EVAPORATOR CLEANER ROCK 250 ML" adalah 10,8 blok dibulatkan menjadi 11 blok. Kebutuhan ruang untuk tiap jenis produk basah dapat dilihat pada tabel dibawah ini.

TABEL VII

KEBUTUHAN RUANG PRODUK BASAH

\begin{tabular}{|c|c|c|c|c|c|}
\hline No & $\begin{array}{l}\text { Kode } \\
\text { Barang }\end{array}$ & Nama Barang & $\begin{array}{c}\text { Keb. } \\
\text { Luas } \\
\text { Tot }\end{array}$ & $\begin{array}{c}\text { SR } \\
\text { Teori } \\
\text { tis }\end{array}$ & $\begin{array}{c}\text { SR } \\
\text { Aktual }\end{array}$ \\
\hline 1 & $\begin{array}{l}\text { DVG92 } \\
\text { F90557 }\end{array}$ & $\begin{array}{c}\text { AC EVAPORATOR } \\
\text { CLEANER ROCK } \\
250 \mathrm{ML}\end{array}$ & $\begin{array}{c}4.320 \\
\mathrm{~cm} 2\end{array}$ & 10,8 & 11 \\
\hline 2 & $\begin{array}{c}\text { DVG513 } \\
00541\end{array}$ & $\begin{array}{c}\text { ACCU GS NS } 40 \\
\text { HYB } 12 v 32 A h\end{array}$ & $\begin{array}{c}3.600 \\
\mathrm{~cm} 2\end{array}$ & 9 & 9 \\
\hline 3 & $\begin{array}{l}\text { DVG51 } \\
\text { B70541 }\end{array}$ & AIR ACCU AA & $\begin{array}{c}17.280 \\
\mathrm{~cm} 2\end{array}$ & 43,2 & 44 \\
\hline 4 & $\begin{array}{c}\text { DVG424 } \\
20548\end{array}$ & $\begin{array}{c}\text { ASTRA SHELL } \\
\text { HELIX 10W30 SM } \\
\text { (BTL) }\end{array}$ & $\begin{array}{c}10.800 \\
\mathrm{~cm} 2\end{array}$ & 27 & 27 \\
\hline 5 & $\begin{array}{c}\text { DVG424 } \\
20546\end{array}$ & $\begin{array}{l}\text { ASTRA SHELL } \\
\text { HELIX 10W40 SL } \\
\text { (BTL) }\end{array}$ & $\begin{array}{c}10.800 \\
\mathrm{~cm} 2\end{array}$ & 27 & 27 \\
\hline . & . & . & $\cdot$ & & $\cdot$ \\
\hline 33 & $\begin{array}{l}\text { DVG61 } \\
\text { O70548 }\end{array}$ & $\begin{array}{c}\text { WIPER FLUID } \\
\text { SAFECLEAN } \\
100 \mathrm{ML}\end{array}$ & $\begin{array}{c}2.520 \\
\mathrm{~cm} 2\end{array}$ & 6,3 & 7 \\
\hline
\end{tabular}

Sedangkan untuk kebutuhan ruang untuk jenis produk kering dapat dilihat pada tabel berikut ini.

TABEL VIII

KEBUTUHAN RUANG PRODUK KERING

\begin{tabular}{|c|c|c|c|c|c|}
\hline No & $\begin{array}{c}\text { Kode } \\
\text { Barang }\end{array}$ & Nama Barang & $\begin{array}{c}\text { Keb. } \\
\text { Luas } \\
\text { Tot }\end{array}$ & $\begin{array}{c}\text { SR } \\
\text { Teori } \\
\text { tis }\end{array}$ & $\begin{array}{c}\text { SR } \\
\text { Aktual }\end{array}$ \\
\hline 1 & $\begin{array}{c}\text { DVG666 } \\
70541\end{array}$ & $\begin{array}{l}\text { "GASKET PLUG } \\
\text { T/M,DIFF." }\end{array}$ & $\begin{array}{l}250 \\
\mathrm{~cm}^{2}\end{array}$ & 1,6 & 2 \\
\hline 2 & $\begin{array}{c}\text { DVG623 } \\
10541\end{array}$ & $\begin{array}{c}\text { ACTUATOR } \\
\text { CENTRAL LOCK. }\end{array}$ & $\begin{array}{l}120 \\
\mathrm{~cm}^{2}\end{array}$ & 0,8 & 1 \\
\hline 3 & $\begin{array}{l}\text { DVG40 } \\
\text { Q90541 }\end{array}$ & $\begin{array}{c}\text { BAHAN } \\
\text { PEMBERSIH BR }\end{array}$ & $\begin{array}{l}1.200 \\
\mathrm{~cm}^{2}\end{array}$ & 8 & 8 \\
\hline 4 & $\begin{array}{l}\text { DVG515 } \\
40541\end{array}$ & BATERAI GP 27A & $\begin{array}{l}375 \\
\mathrm{~cm}^{2}\end{array}$ & 2,5 & 3 \\
\hline 5 & $\begin{array}{c}\text { DVG318 } \\
50541\end{array}$ & BAUT MUR 10 & $\begin{array}{l}135 \\
\mathrm{~cm}^{2}\end{array}$ & 0,9 & 1 \\
\hline . & . & . & . & & . \\
\hline . & & . & . & & . \\
\hline 64 & $\begin{array}{c}\text { DVG546 } \\
70541\end{array}$ & TERMINAL 12 & $80 \mathrm{~cm}^{2}$ & 0,53 & 1 \\
\hline
\end{tabular}




\section{B. Perhitungan Aktivitas dan Penempatan Produk (Troughput dan Assignment)}

Perhitungan Troughput didasarkan pada aktivitas penerimaan dan pengiriman produk dengan diasumsikan proses perpindahan dilakukan secara manual dan kapasitas angkut maksimal adalah 2 kardus dengan ukuran $50 \mathrm{~cm}$ x 40 $\mathrm{cm}$ per sekali jalan. Satuan yang digunakan untuk barang masuk adalah "dus" dikarenakan pekerja mendapatkan barang masuk berupa dus dan akan dipindahkan lokasi penyimpan berupa dus, sedangkan untuk satuan barang keluar menggunakan "pcs" karena barang keluar satu persatu unit. Berikut adalah contoh perhitungan untuk troughput produk "AC EVAPORATOR CLEANER ROCK $250 \mathrm{ML} "$

$$
\begin{aligned}
& T=\frac{6 d u s}{2 d u s}+\frac{48 p c s}{1 p c s} \\
& T=51
\end{aligned}
$$

Setelah didapatkan nilai troughput, dilakukan perhitungan assignment dengan cara membagi antara kebutuhan ruang dengan nilai throughput. Nilai assignment selanjutnya diurutan mulai dari yang terbesar dengan tujuan nilai assignmet yang lebih besar perlu mendapat prioritas jarak yang lebih dekat. Berikut adalah tabel hasil perhitungan untuk produk jenis basah.

TABEL IX

\begin{tabular}{|c|c|c|c|c|c|}
\hline No & $\begin{array}{l}\text { Kode } \\
\text { Barang }\end{array}$ & Nama Barang & $\begin{array}{l}\text { Keb. } \\
\text { ruang }\end{array}$ & $\mathrm{T}$ & $\mathrm{T} / \mathrm{S}$ \\
\hline 1 & $\begin{array}{l}\text { DVG61 } \\
\text { O70548 }\end{array}$ & $\begin{array}{c}\text { WIPER FLUID } \\
\text { SAFECLEAN 100ML }\end{array}$ & 7 & 85 & 12.15 \\
\hline 2 & $\begin{array}{l}\text { DVG72 } \\
\text { A51533 }\end{array}$ & $\begin{array}{c}\text { FUEL INJECTION } \\
\text { CLEANER ROCK } \\
250 \mathrm{ML}\end{array}$ & 8 & 97 & 12.12 \\
\hline 3 & $\begin{array}{c}\text { DVG713 } \\
80541\end{array}$ & ENGINE FLUSH & 8 & 93 & 12 \\
\hline 4 & $\begin{array}{l}\text { DVG51 } \\
\text { B70541 }\end{array}$ & AIR ACCU AA & 44 & 456 & 10.37 \\
\hline 5 & $\begin{array}{c}\text { DVG841 } \\
04715\end{array}$ & $\begin{array}{l}\text { ECO RADIATOR } \\
\text { TREATMENT }\end{array}$ & 7 & 72 & 10.28 \\
\hline$\cdot$ & . & . & . & & . \\
\hline 33 & $\begin{array}{l}\text { DVG11 } \\
\text { P41315 }\end{array}$ & $\begin{array}{c}\text { CASTROL } \\
\text { MAGNATEC 5W-30 } \\
\text { SM/CF (B) }\end{array}$ & 8 & 2 & 0.25 \\
\hline
\end{tabular}

PERHITUNGAN ASSIGNMENT PRODUK BASAH

Sedangkan untuk hasil perhitungan untuk jenis produk kering dapat dilihat pada Tabel $\mathrm{X}$ berikut ini.

TABEL X

\begin{tabular}{|c|c|c|c|c|c|}
\hline No & $\begin{array}{c}\text { Kode } \\
\text { Barang }\end{array}$ & Nama Barang & $\begin{array}{l}\text { Keb. } \\
\text { ruang }\end{array}$ & $\mathrm{T}$ & $\mathrm{T} / \mathrm{S}$ \\
\hline 1 & $\begin{array}{c}\text { DVG666 } \\
50541\end{array}$ & $\begin{array}{c}\text { GASKET PLUG E/G } \\
\text {.F\#. }\end{array}$ & 4 & 643 & 160.75 \\
\hline 2 & $\begin{array}{c}\text { DVG666 } \\
60541\end{array}$ & $\begin{array}{c}\text { GASKET PLUG E/G } \\
\text { S\#. }\end{array}$ & 2 & 164 & 82 \\
\hline 3 & $\begin{array}{c}\text { DVG666 } \\
70541\end{array}$ & $\begin{array}{l}\text { "GASKET PLUG } \\
\text { T/M,DIFF." }\end{array}$ & 2 & 61 & 30.5 \\
\hline 4 & $\begin{array}{c}\text { DVG318 } \\
50541\end{array}$ & BAUT MUR 10 & 1 & 21 & 21 \\
\hline 5 & $\begin{array}{c}\text { DVG00I } \\
80551\end{array}$ & PLASTIGAGE & 1 & 13 & 13 \\
\hline . & · & . & . & & . \\
\hline 64 & $\begin{array}{l}\text { DVG53 } \\
\text { Y50541 }\end{array}$ & BENSTECH & 4 & 2 & 0.3 \\
\hline
\end{tabular}

PERHITUNGAN ASSIGNMENT PRODUK KERING
TABEL X (LANJUTAN)

PERHITUNGAN ASSIGNMENT PRODUK KERING

\begin{tabular}{cccccc}
\hline \hline No & $\begin{array}{c}\text { Kode } \\
\text { Barang }\end{array}$ & Nama Barang & $\begin{array}{c}\text { Keb. } \\
\text { ruang }\end{array}$ & T & T/S \\
\hline$\cdot$ & $\cdot$ & $\cdot$ & $\cdot$ & & $\cdot$ \\
64 & $\cdot$ & $\cdot$ & $\cdot$ & 2 &. \\
& DVG53 & BENSTECH & 4 & 2 & 0.3 \\
\hline \hline
\end{tabular}

\section{Penyusunan Tata Letak Gudang Baru dan Penataan Produk}

Berdasarkan kebutuhan ruang yang sudah dihitung sebelumnya,, maka dilakukan perancangan tata letak gudang yang baru untuk nantinya digunakan untuk menyimpan produk. Berikut adalah desain tata letak gudang yang baru dengan menyesuaikan kebutuhan ruangan.

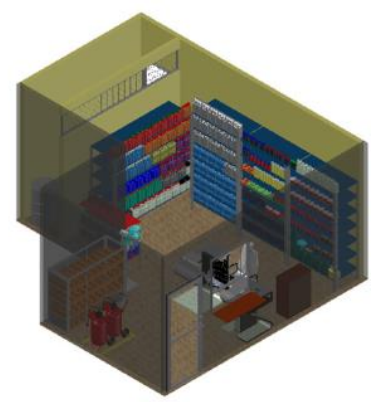

Gambar. 5. Denah Gudang Baru Tampak Kiri 3D

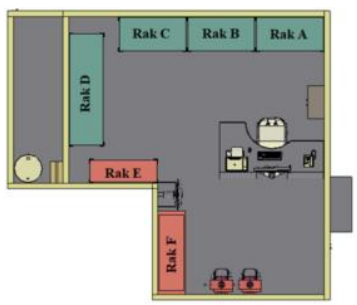

Gambar. 6. Layout Gudang Non Genuine Baru

Untuk penentuan lokasi penempatan setiap jenis produk didasarkan pada nilai $\mathrm{T} / \mathrm{S}$, dimana semakin besar nilai $\mathrm{T} / \mathrm{S}$ maka lokasi penempatan produk harus paling dekat dengan lokasi masuk/keluar produk. Berikut adalah hasil penentuan lokasi produk yang baru.

TABEL XI

\begin{tabular}{|c|c|c|c|c|c|}
\hline No & $\begin{array}{l}\text { Kode } \\
\text { Barang }\end{array}$ & Nama Barang & $\begin{array}{l}\text { Lok. } \\
\text { Asal }\end{array}$ & $\begin{array}{l}\text { Lok. } \\
\text { Baru }\end{array}$ & $\begin{array}{c}\text { Selisih } \\
\text { Jarak }\end{array}$ \\
\hline 1 & $\begin{array}{c}\text { DVG666 } \\
70541\end{array}$ & $\begin{array}{l}\text { GASKET PLUG } \\
\text { T/M,DIFF }\end{array}$ & $\mathrm{H}$ & $\mathrm{F}$ & $-3,5 \mathrm{~m}$ \\
\hline 2 & $\begin{array}{l}\text { DVG92 } \\
\text { F90557 }\end{array}$ & $\begin{array}{c}\text { AC EVAPORATOR } \\
\text { CLEANER ROCK } 250 \\
\text { ML }\end{array}$ & A & $\begin{array}{c}\text { B \& } \\
\text { A }\end{array}$ & $-1,4 \mathrm{~m}$ \\
\hline 3 & $\begin{array}{c}\text { DVG513 } \\
00541\end{array}$ & $\begin{array}{c}\text { ACCU GS NS } 40 \text { HYB } \\
12 v 32 A h\end{array}$ & $\mathrm{D}$ & $\mathrm{D}$ & $-0,1 \mathrm{~m}$ \\
\hline 4 & $\begin{array}{c}\text { DVG623 } \\
10541\end{array}$ & $\begin{array}{c}\text { ACTUATOR } \\
\text { CENTRAL LOCK. }\end{array}$ & B & $\mathrm{F}$ & $-2,5 \mathrm{~m}$ \\
\hline 5 & $\begin{array}{l}\text { DVG51 } \\
\text { B70541 }\end{array}$ & AIR ACCU AA & G & B & $+1,85 \mathrm{~m}$ \\
\hline . & . & . & . & & . \\
\hline 97 & $\begin{array}{l}\text { DVG61 } \\
\text { O70548 }\end{array}$ & $\begin{array}{c}\text { WIPER FLUID } \\
\text { SAFECLEAN 100ML }\end{array}$ & B & B & $0,2 \mathrm{~m}$ \\
\hline
\end{tabular}

PELETAKAN PRODUK PADA LOKASI BARU 
Hasil dari penataan produk di tata letak yang baru didapatkan jumlah jarak perpindahan per bulan sebesar 12.942,2. Dimana angka ini lebih kecil 24\% dari jarak perpindahan sebelum perbaikan tata letak. Hal ini menunjukan dengan perubahan tata letak yang baru, maka proses perpindahan produk di gudang non genuine menjadi lebih efisien dan setiap produk memiliki lokasi yang pasti.

\section{KESIMPULAN}

Dari penelitian ini, dapat diperoleh kesimpulan sebagai berikut:

1) Penataan lokasi penyimpanan dalam gudang non genuine yang sebelumnya memiliki 8 lokasi penyimpanan, diubah menjadi 6 lokasi penyimpanan yang terdiri dari 5 rak untuk jenis produk basah dan 1 rak untuk jenis produk kering.

2) Hasil penentuan lokasi peletakan untuk masing-masing produk berdasarkan metode dedicated diketahui dapat menghemat jarak perpindahan total per bulan yang sebelumnya 17.057,6 meter menjadi $12.942,2$ meter atau mengurangi jarak sebesar $24 \%$.

\section{DAFTAR PUSTAKA}

[1] Wignjosoebroto, S.,Tata Letak Pabrik dan Pemindahan Bahan, Surabaya, Penerbit Guna Widya, 1996

[2] Apple, J.M., Tata Letak Pabrik Dan Pemindahan Bahan, Diterjemahkan Oleh Nurhayati Mardiono, ITB. Bandung. 1990

[3] Francis, R. L., McGrinnis Jr, L. f., and White, J. A., Facility Layout and Location: An Analytical Approach. 2nd Ed. New Jersey, Pretince-Hall Inc, 1992

[4] Tompkins, J. A., dan White, J. A., Bozer, Y.A., dan Tanchoco, J.M.A., Facilities Planning. Fourth Edition. New York, John, Wiley, 2010 